\title{
A Method for Manufacturing of Bonito Spermary Extract by Autolysis
}

\author{
Kenzo Toyama,* Tetsuhito Hayashi,* Etsuo Watanabe,* \\ Tomoko Kawamura, ${ }^{*}$ and Yuko Murata*
}

(Received May 22, 1989)

\begin{abstract}
From the view point of effective utilization of fisheries by-products, a method for manufacturing bonito spermary extracts by autolysis was examined. The optimum lysing temperature was found at $60^{\circ} \mathrm{C}, \mathrm{pH} 7.5$ with two parts of water. The extract obtained from $20 \mathrm{~h}$ autolysates showed favorable characteristic flavor. It was rich in free amino acid and 5'-nucleotide. Total amount of Arg, His, Glu, Ala, and Tau accounted for more than $70 \%$ of that of total free amino acid. Thus the products was expected to be used as characteristic and unique seasoning extract.
\end{abstract}

The total catch of bonito amounts to about 300 350 thousand tons annually in Japan. They have a comparatively large body and are served not only as Sashimi (sliced raw fish) but also as canned products or Katsuwobushi, a traditional dried fish prepared by smoking. Most of the viscera are utilized as Shiokara, a seasoned and fermented food. However, their reproductive organs (the spermary and ovary) are utilized as fish or some livestock feed or organic fertilizer. In the last several years protamine, one of the major spermary proteins, has been reported to have an active anti-bacterial action ${ }^{1,2}$ and has been examined for use as food preservative. ${ }^{3)}$

As fish reproductive organs, especially spermary, contain some unique and tasty components characteristic of each fish, Japanese people like to eat as local food. ${ }^{4}$ However, bonito spermary is not so eaten though the reason is not obvious. We have tried to get fish extract of superior quality from bonito spermary. This paper deals with a method for preparaing the extract by autolysis and describes the chemical nature of its constituents.

\section{Materials and Methods}

\section{Materials}

Freshly frozen bonito spermary was supplied by a Katsuwobushi manufacturer, Yaizu, Shizuoka Prefecture, in October 1986 . It was kept at $-25^{\circ} \mathrm{C}$ until use. A $500 \mathrm{~g}$ portion of the frozen block was cut out at each experiment, put into a polyethylene bag and thawed in running water. After thawing, it was washed quickly with tap water and cleaned to remove blood vessels distributed on its surface. The cleaned raw material was chopped by a hand-operated mincer equipped with a $7-\mathrm{mm}$ diameter hole blade.

\section{Autolysis of Spermary and Extract Preparation}

Autolysis was carried out in a cylindrical glass reaction vessel, $14 \mathrm{~cm}$ in diameter and $18 \mathrm{~cm}$ in depth, equipped with a four blade stirrer and a reflux condenser. The reaction bath was immersed in a water bath of $6 \mathrm{~cm}$ in depth. First, a $500 \mathrm{~g}$ portion of minced spermary was autolyzed at four different temperatures $\left(40^{\circ} \mathrm{C}, 50^{\circ} \mathrm{C}, 60^{\circ} \mathrm{C}\right.$, and $70^{\circ} \mathrm{C}$ ) to determine the optimum temperature. Then, six different ratios of water, $(12.5,25,100$, 200 , and $400 \%$ of the sample weight) were added to each raw material before the start of the reaction to determine the proper addition of water on the recovery of extractive material. In the last step of this experiment, several different $\mathrm{pHs}$ (6.4-8.0) were applied by addition of $6 \mathrm{~N}$ and $1 \mathrm{~N} \mathrm{HCl}$ or $6 \mathrm{~N}$ and $1 \mathrm{~N} \mathrm{NaOH}$ to find out the optimum $\mathrm{pH}$.

\section{Preparation of Press Juice and Extract from Au- tolysate}

The autolysate was pressed in a bag made of Tetoron ${ }^{\circledR}$ yarn to recover press juice. The press cake was stirred again with the additional $200 \mathrm{~m} l$ of water for $1 \mathrm{~h}$ at the same temperature being used for the autolysis. In some cases instead of compression, centrifugation was also employed to eliminate the adsorption loss of the press juice by the press bag. Centrifugal conditions were

* Department of Food Science and Technology, Tokyo University of Fisheries, Konan, Minato, Tokyo 108 Japan (外山健三, 林 哲仁, 渡辺悦生, 河村朋子, 村田裕子: 東京水産大学食品生座学科). 
$8,000 \mathrm{rpm}(10,500 \times \mathrm{g})$ for $15 \mathrm{~min}$ at $4^{\circ} \mathrm{C}$.

To prepare the extract, the press juice was deproteinized by an addition of ethanol to a concentration of $80 \%$. Upon separation of the denaturated protein by centrifugation, the supernatant was concentrated by evaporation under reduced pressure to remove ethanol. The concentrate was defatted by washing three times with the same volume of diethyl ether and then made up to $100 \mathrm{~m} /$ with water in case the starting raw material was $100 \mathrm{~g}$.

\section{Chemical Analyses of the Extract}

1. Total nitrogen. Total nitrogen was determined by macro-Kjeldahl method after AOAC using Quick Digestive and Distillating System (Mitamura Co., Tokyo). All data shown in this paper are expressed as mg-nitrogen per $100 \mathrm{~g}$ minced raw material.

2. Approximate amino acid concentration of autolyzate. An absorbance of the supernatant of autolysate at $275 \mathrm{~nm}$ was measured after being diluted to an appropriate concentration to estimate the increase of free amino acid concentrations with the progress of digestion.

3. Total amino acid in the autolysate. Total amino acid was measured by JEOL JLC-6AS automatic amino acid analyzer after the sample was hydrolyzed with $6 \mathrm{~N}$ hydrochloric acid at $110^{\circ} \mathrm{C}$ for $20 \mathrm{~h}$.

4. Total amino acid in the press juice. Press juice was separated from the autolysate by the centrifugation at $8,000 \mathrm{rpm}(10,500 \times \mathrm{g})$ at $2^{\circ} \mathrm{C}$ for $20 \mathrm{~min}$. Upon hydrolysis of the press juice, amino acids were determined by the same manner as mentioned above.

5. Combined amino acids in the extract. The extract was hydrolyzed to determine combined amino acids which consisted of peptides by the deduction of free amino acids from the analytical data.

6. Free amino acid in the extract. Free amino acids were determined on a Shimadzu amino acid analyzer consisting of LC-6A HPLC modules and a malti-gradient elution system with lithium citrate buffers for physiological fluid analysis. Each amino acids were derivatized with OPA upon elution from a cation exchange resin column (Shim-pack ISCO/S150 L Li, $4 \times 150 \mathrm{~mm}$ ).

7. Nucleotides and their related compounds in the extract. The extract was pretreated by passing through the Dowex 1-X4 column. Nucleotides were separated with each other by HPLC using strongly basic anion exchange column Shim-pack WAX-1 $(4 \times 50 \mathrm{~mm})$ and stepwise gradient of phosphate buffers (A: $20 \mathrm{~mm}, \mathrm{pH} 7.00$, B: $480 \mathrm{~mm}, \mathrm{pH} 6.00$ ) at $45^{\circ} \mathrm{C}$ at the flow rate of $1 \mathrm{~m} / / \mathrm{min}$. Nucleosides and free bases were separated on reversed phase Shim-pack CLCODS with linear gradient elution of $0.1 \mathrm{M}$ phosphate buffer $(\mathrm{pH} 2.0$ ) and $0.2 \mathrm{M}$ sodium perchlorate. Individual peak was detected at $260 \mathrm{~nm}$ and calculated automatically using the C-R3A data-processor.

8. Trimethylamine (TMA) and trimethylamine oxide (TMAO) in the extract. TMA in the acidic extract of the autolysate was diluted to the appropriate concentration and determined quantitatively as follows. Two $\mathrm{m} l$ of the extract was mixed with $1 \mathrm{~m} l$ of diethyl ether and $2 \mathrm{ml}$ of $65 \%$ $\mathrm{KOH}$ and shaken vigorously for $1 \mathrm{~min}$. One $\mu l$ of ether layer was injected into GLC (Shimadzu GC-7A) equipped with a packed glass column $(3 \mathrm{~mm} \times 2 \mathrm{~m})$ of squalane $(20 \%)+$ glycerine $(2.5 \%)$ $+\mathrm{KOH}(2.5 \%)$ on Diasolid L (80-100 mesh). Temperatures of injection port and column oven were $80^{\circ} \mathrm{C}$ and $50^{\circ} \mathrm{C}$, respectively. Flow rate of carrier nitrogen gas was $20 \mathrm{~m} / / \mathrm{min}$. TMAO was reduced to TMA by the addition of equal volume of $20 \% \mathrm{TiCl}_{3}$ and kept standing at room temperature for $2 \mathrm{~h}$. After an excess reducing reagent was neutralized by the addition of 2-3 drops of saturated $\mathrm{KNO}_{3}$, TMA was analyzed by the same GLC manner as mentioned above. The amount of total TMA in the test solution gave that of TMAO by calculation.

9. Organic acids in the extract. The extract was passed continuously through columns of Dowex 50 W-X8 and Amberlite IRA-45. After the columns were washed with water, $1 \mathrm{~N} \mathrm{NaOH}$ solution was poured into the latter column to elute organic acids. HPLC analysis of organic acids was carried at $50^{\circ} \mathrm{C}$ by an isocratic elution

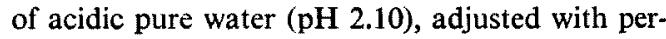
chloric acid at a flow rate of $1.2 \mathrm{~m} / / \mathrm{min}$ using cation exchange resin column Shim-pack SCR$101 \mathrm{H}(7.9 \times 300 \mathrm{~mm})$.

10. Sugars (monosaccharides) in the extract. Sugars were derivatized with TMS regaent in a Reacti-vial (Pearce Co.) and injected into Shimadzu GC-7A equipped with a glass column (3 $\mathrm{mm} \times 2 \mathrm{~m}$ ) packed with GP $3 \% \mathrm{SP}-2330$ on Supelcoport (100-200 mesh). Temperatures of the injection port and the column oven were $260^{\circ} \mathrm{C}$ and $225^{\circ} \mathrm{C}$, respectively. Carrier nitrogen gas was passed through the column at a flow rate of $40 \mathrm{~m} / \mathrm{min}$. 


\section{Results and Discussion}

When fish solubles are manufactured commercially from viscera,, minced raw materials are autolyzed near $50^{\circ} \mathrm{C}$ for $2 \mathrm{~h}$ in some Japanese factories. In the first step of this experiment, similar experimental conditions were employed to establish the optimum temperature in bonito spermary autolysis. The autolysis at $40^{\circ} \mathrm{C}$ was excluded from further experimentation because of its foul smell suggesting the presence of propagating microorganisms. At $50^{\circ} \mathrm{C}, 60^{\circ} \mathrm{C}$, or $70^{\circ} \mathrm{C}$, the minced spermary became an aromatic viscous paste. The press juice obtained was clear, brightyellow and smelled of tasty boiled fish.

However, the amount of the press juice obtained by one squeeze was much lower than expected probably in some part due to its absorption by the press bag. A considerable portion of the extractive compounds seemed to remain in the press cake. Thus $200 \mathrm{~m} l$ of water were added to the press cake and stirred at the same temperature. After $1 \mathrm{~h}$ of stirring, a liquid fraction was separated by the same manner as used for the first separation.

In the next step of this experiment, an appropriate amount of water was added to the minced raw material at the start of the process expecting the hydrolysis of the protein to improve the recovery of juice. The data were compared with that for autolysis without addition of water. At furst, $200 \mathrm{~g}$ of water (being equivalent to $40 \%$ weight of the starting raw material) was added to the reaction system and the increase of press juice was estimated on the weight bases. The data shown in Table 1 indicate the considerable increase of the press juice by addition of water to the reaction system. However, it should be obvious that as more water is added, more press juice would be obtained.

The amount of water soluble nitrogen in the press juice obtained by digestion with or without water at each temperature tested was summarized in Table 2. From these observations the addition of water increased 3 to 4 times the total water soluble nitrogen. The maximum recovery was obtained at $50^{\circ} \mathrm{C}$ and it diminished along with the increase of temperature for autolysis. Water soluble nitrogen thus obtained at $60^{\circ} \mathrm{C}$ with water showed about 7 times higher recovery than that at the same temperature without water. In the case of $50^{\circ} \mathrm{C}$ and $70^{\circ} \mathrm{C}$ with water, the recovered water soluble nitrogen was about 4.7 and 2.5 times higher than those without water. From the results of this experiment, it was confirmed that the addition of water to the minced bonito spermary increased not only the volume of press juice but also increased the recovery of water soluble nitrogenous compounds.

Absorbance at $275 \mathrm{~nm}$ on the same sample was measured and converted into the weight of free tyrosine to estimate the release of free amino acid as indicated in Table 3. In this estimation, the converted tyrosine in an autolysate with water also revealed a higher amount than that of no water addition. When autolyzed at $60^{\circ} \mathrm{C}$, the converted tyrosine in the press juice gave the highest value and it was more than 7.5 times the value of unautolyzed bonito spermary itself.

Table 1. Weight of press juice obtained from $500 \mathrm{~g}$ of the autolysate incubated at 50,60 , and $70^{\circ} \mathrm{C}$ with or without water and that of unautolyzed materials $(\mathrm{g})$

\begin{tabular}{|c|c|c|c|c|c|c|c|}
\hline \multirow{2}{*}{ Temp. incubated $\left({ }^{\circ} \mathrm{C}\right)$} & \multicolumn{3}{|c|}{ without water } & \multicolumn{3}{|c|}{ with water*1 } & \multirow{2}{*}{$\begin{array}{l}\text { unauto- } \\
\text { lyzed }\end{array}$} \\
\hline & 50 & 60 & 70 & 50 & 60 & 70 & \\
\hline First press & 19.0 & 13.0 & 16.5 & 202.5 & 265.0 & 122.5 & 55.0 \\
\hline Second press & 90.5 & 28.5 & 67.0 & 200.5 & 71.0 & 82.0 & 124.0 \\
\hline Total & 109.5 & 41.5 & 83.5 & 403.0 & 336.0 & 204.5 & 179.0 \\
\hline
\end{tabular}

*1 Water was added at a level of $40 \%$.

Table 2. Extractive nitrogen in the press juice autolyzed at 50,60 , and $70^{\circ} \mathrm{C}$ with or without water and that of unautolyzed materials ( $\mathrm{mg}$ nitrogen/100 $\mathrm{g}$ of minced material)

\begin{tabular}{lrrrrrrrr}
\hline & \multicolumn{3}{c}{ without water } & & \multicolumn{3}{c}{ with water*1 } & \multicolumn{2}{c}{ unauto- } \\
Temp. incubated $(\mathrm{C})$ & 50 & 60 & 70 & & 50 & 60 & 70 & lyzed \\
& 28 & 17 & 15 & 247 & 161 & 151 & 18 \\
\hline First press & 49 & 22 & 80 & 122 & 80 & 87 & 35 \\
Second press & 77 & 39 & 95 & 369 & 241 & 238 & 53 \\
Total & & &
\end{tabular}

* 1 See the footnote of Table 1 . 
Table 3. Tyrosine equivalent concentration liberated during the autolysis at 50,60 , and $70^{\circ} \mathrm{C}$ with or without water and that of unatolyzed minced materials (mg tyrosine $/ 100 \mathrm{~g}$ of minced material)

\begin{tabular}{|c|c|c|c|c|c|c|c|}
\hline \multirow{2}{*}{ Temp. incubated $\left({ }^{\circ} \mathrm{C}\right)$} & \multicolumn{3}{|c|}{ without water } & \multicolumn{3}{|c|}{ with water*1 } & \multirow{2}{*}{$\begin{array}{l}\text { unauto- } \\
\text { lyzed }\end{array}$} \\
\hline & 50 & 60 & 70 & 50 & 60 & 70 & \\
\hline First press & 51.0 & 100.0 & 97.2 & 519.7 & 958.8 & 454.4 & 44.4 \\
\hline Second press & 121.6 & 118.1 & 227.3 & 284.6 & 266.0 & 319.1 & 92.3 \\
\hline Total & 172.6 & 218.1 & 324.5 & 804.3 & 1124.8 & 773.5 & 136.7 \\
\hline
\end{tabular}

*1 See the footnote of Table 1 .

Table 4. Weight of the juice squeezed by centrifuging $500 \mathrm{~g}$ of autolysates incubated at $60^{\circ} \mathrm{C}$ with 6 different portions of water $(\mathrm{g})$

\begin{tabular}{lrrrrrr}
\hline \hline Water added (\%) & 12.5 & \multicolumn{1}{c}{25} & \multicolumn{1}{c}{50} & \multicolumn{1}{c}{100} & \multicolumn{1}{c}{200} & \multicolumn{1}{c}{400} \\
\hline First centrifugation & 28.6 & 95.2 & 57.7 & 96.6 & 173.6 & 316.2 \\
Second centrifugation & 66.4 & 35.2 & 36.1 & 37.4 & 35.0 & 76.5 \\
Total & 95.0 & 130.4 & 93.8 & 134.0 & 208.6 & 392.7 \\
\hline
\end{tabular}

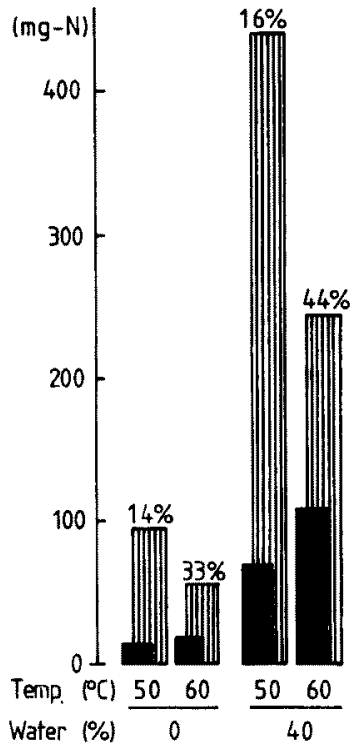

Fig. 1. Ratio of amino acid nitrogen to total extractive nitrogen in the press juice autolyzed at 50 and $60^{\circ} \mathrm{C}$ with $(40 \%)$ or without water. Columns filled with vertical lines and painted out with black indicate total extractive nitrogen and amino acid nitrogen, respectively. Arabic numerals given on the columns show ratios of two nitrogens. $(\%)$.

Since the optimum autolyzing temperature was not clearly established from the above results, the ratio of free amino acid nitrogen to total extractable nitrogen in each sample autolyzed at $50^{\circ} \mathrm{C}$ and $60^{\circ} \mathrm{C}$ was calculated and shown in Fig. 1. The results clearly indicate a remarkable recovery of amino acid and perhaps an acceleration of the digestion process of the bonito spermary. The ratio of amino acid nitrogen to total nitrogen in the autolysate incubated at $60^{\circ} \mathrm{C}$ showed $2.3-2.8$ times higher than those incubated at $50^{\circ} \mathrm{C}$, so it was concluded that the optimum autolyzing temperature was $60^{\circ} \mathrm{C}$ as long as the amount of digested nitrogenous products was thought to be one of the efficiency index.

Six different volumes of water, which represented $12.5,25,50,100,200$, and $400 \%$ of raw material weight, were added to the minced spermary in order to determine an optimum volume of water. In this study, centrifugation at $8,000 \mathrm{rpm}(10,500 \times$ g) for $20 \mathrm{~min}$ was adopted instead of hand press to reduce the loss of extract in the course of separation. Table 4 shows the total volume of the extract obtained from the first and second centrifugations. The amount of extractive nitrogen in the press juice separated from each autolysate incubated with 6 different volumes of water was given in Table 5. Out of 6 autolysates thus obtained, $50 \%$ addition of water gave the least extractive nitrogen and $12.5,25$, and $100 \%$ addition showed only a little increase. Both 200 and $400 \%$ addition showed better nitrogen extractability than other 4 experimental conditions. As shown in Table 4, the amount of extract separated by centrifugation increased in proportion to the volume of water added. Between these two amounts, the $200 \%$ addition of water was found to be the optimum when the energy saving in concentration process was taken into consideration.

The minced raw material with $200 \%$ water was 
Table 5. Extractive nitrogen in the press juice squeezed from autolysate incubated at $60^{\circ} \mathrm{C}$ with 6 different portions of water (mg-nitrogen $/ 100 \mathrm{~g}$ minced material)

\begin{tabular}{lrrrrrr}
\hline \multicolumn{1}{c}{ Water added $(\%)$} & 12.5 & \multicolumn{1}{c}{25} & \multicolumn{1}{c}{50} & \multicolumn{1}{c}{100} & \multicolumn{1}{c}{200} & \multicolumn{1}{c}{400} \\
\hline First centrifugation & 135.2 & 247.2 & 182.0 & 216.9 & 325.7 & 329.5 \\
Second centrifugation & 138.8 & 47.3 & 38.3 & 39.5 & 33.8 & 32.5 \\
Total & 274.0 & 294.5 & 220.3 & 256.4 & 359.5 & 362.0 \\
\hline
\end{tabular}

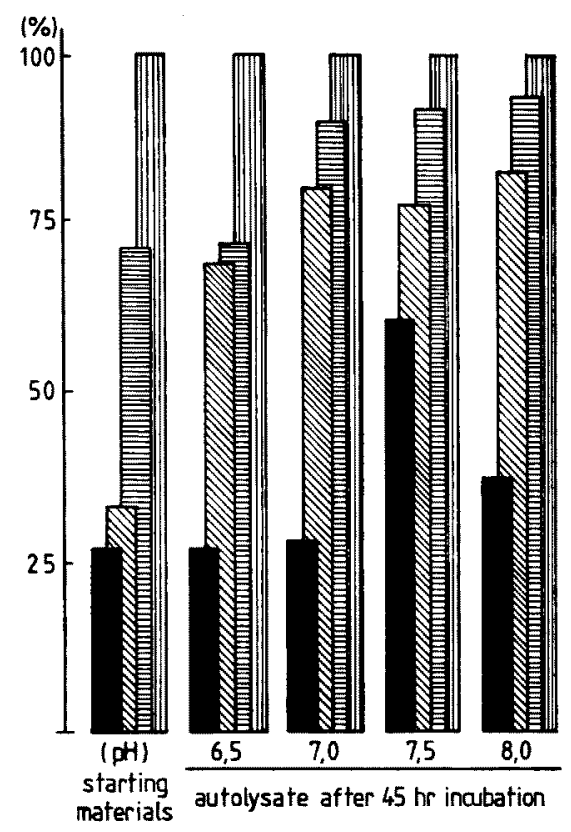

Fig. 2. Ratios of water-soluble proteinous, combined, and free amino acids in the extracts autolyzed at different $\mathrm{pHs}$ to total amino acid in the starting minced materials. Columns filled with virtical lines indicate, total amino acids in the starting materials; with horizontal line, water soluble proteinous amino acid; and with oblique line, combined amino acid; painted out with black, free amino acid.

adjusted to four different $\mathrm{pHs}$ of $6.5,7.0,7.5$, and 8.0. All these test samples were incubated at $60^{\circ} \mathrm{C}$, the optimum autolyzing temperature. Proportion of total, combined, and free amino acids in the extracts, which were prepared from the autolysates adjusting to the four different $\mathrm{pH}$ and taken out at $45 \mathrm{~h}$ after the reaction started, were compaired to the total amono acid of minced raw material with twice amount of water just before the start of autolyzation. An increase of total weight of each amino acid specimen samples during the 45-hr incubation is shown in Fig. 2. The highest recovery of free amino acids by the autolysis at pH 7.5 accounted for $60 \%$ of the total amino acid and was more than twice as much as that in the raw material. The highest free amino acid recovery indicates the optimum $\mathrm{pH} 7.5$ for the bonito spermary extract preparation.

In the last step of this study, the chemical composition of the final products were analyzed in detail. The products were prepared by the autolysis under the optimum and two other conditions as described above. Analytical results are summarized in Table 6.

Among free amino acids, Tau a nonproteinous amino acid was the most aboundant $(350 \mathrm{mg}$ in $100 \mathrm{~g}$ of starting material). Basic amino acids, such as Arg, His, and Lys, were the second richest (50-110 mg,) followed by Glu, Ala, and Leu at a little lower level. The sum amount of these 7 amino acids comprised about three-fourth of the total amino acids. In general, fish spermary is composed of the nucleic protein protamine which consists of Arg as a major amino acid. Although Arg accounts for the most part of the total amino acids which are obtained after complete acid hydrolysis, our data on the autolysate shown in Table 6 did not confirm this. Since the autolytic enzyme in the spermary has not been separated or characterized yet, the reason for the above mentioned phenomenon is not known. Presumably, the major enzyme responsible for the autolysis is endopeptidases and not exopeptidases.

Among compounds related to nucleic acids, about $20 \mathrm{mg}$ of IMP and UMP each was detected as 5 -nucleotide and only a trace amount of nucleosides was found to exist. Besides these compounds, three free nucleobases were determined for $10 \mathrm{mg}$ order. Both sugars and TMAO were found to be below the detection limit. In organic acid, only a few $\mathrm{mg}$ of propionic acid was detected together with a trace of acetic acid.

An autolytic extract of bonito spermary had strong sweetness and Umami (glutamate-like meaty taste), with weak saltiness, but had no bitterness and sourness at all. The product was clear and light bright yellow in color. It had almost no specific spermine like odor which was characteristic of raw fish spermary and its products. 
Table 6. Extractive nitrogenous components in the autolysate produced with 3 different portions of water $(\mathrm{mg} / 100 \mathrm{~g})$

\begin{tabular}{|c|c|c|c|c|c|c|c|}
\hline Water $(\%)$ & 25 & 100 & 200 & Water $(\%)$ & 25 & 100 & 200 \\
\hline Tau & 347 & 384 & 354 & AMP & - & - & 5 \\
\hline Asp & 32 & 34 & 30 & CMP & 9 & - & - \\
\hline Thr & 28 & 25 & 24 & IMP & 34 & 36 & 6 \\
\hline Ser & 37 & 37 & 38 & UMP & 49 & 33 & 25 \\
\hline Glu & 95 & 102 & 77 & Total & 92 & 69 & 36 \\
\hline Pro & 16 & 30 & + & & & & \\
\hline Gly & 49 & 55 & 44 & $\mathrm{Ado}^{\mathrm{a}}$ & 3 & - & 4 \\
\hline Ala & 73 & 70 & 67 & Guo $^{b}$ & 1 & - & - \\
\hline Val & 39 & 34 & 37 & $\mathrm{Uri}^{\mathrm{e}}$ & - & 8 & - \\
\hline Met & 21 & 21 & 15 & $\operatorname{Ade}^{d}$ & 24 & 7 & 5 \\
\hline Ile & 28 & 21 & 20 & $\mathrm{Cyt}^{\circ}$ & 21 & 18 & 20 \\
\hline Leu & 62 & 46 & 55 & $\mathrm{Ura}^{\mathrm{f}}$ & 30 & 7 & 5 \\
\hline Tyr & 42 & 30 & 45 & Total & 79 & 40 & 34 \\
\hline Phe & 33 & 26 & 34 & & & & \\
\hline His & 107 & 77 & 106 & $\mathrm{PA}^{\mathrm{g}}$ & 86 & 29 & 6 \\
\hline Lys & 56 & 42 & 54 & $\mathrm{AA}^{\mathrm{b}}$ & - & 1 & 1 \\
\hline Arg & 115 & 86 & 144 & Total & 86 & 30 & 7 \\
\hline Total & 1175 & 1120 & 1146 & & & & \\
\hline
\end{tabular}

(a) Ado=adenosine, (b) Guo = guanosine, (c) Uri=uridine, (d) Ade=adenine, (e) Cyt =cytosine, (f) Ura =uracil, (g) = PA propionic acid, (h) $A A=$ acetic acid.

Its flavor was weak but similar to dried bonito. The viscosity of the final product was quite low.

In conclusion, the manufactured autolytic extract of bonito spermary was rich in free amino acids whose profile was somewhat different from that of fish meat extract. ${ }^{6)}$ It was also aboundant in taste-active $5^{\prime}$-nucleotide whose level was a little higher than that of ordinary fish muscle extract." Our product could be used as a manufacturing material to blend with other types of fish, meat or vegetable extract in order to produce a characteristic and unique seasoning extract.

\section{Acknowledgements}

We are greatly indebted to Marutomo Co., Iyo, Ehime., for the support in promoting this study, and to Marute-Kobayashi Shoten Co., Yaizu, and Yanagiya-Honten Co., Yaizu, Shizuoka., for their kind supply of bonito spermary.

We wish to thank Dr. Thomas G. Stackhouse,
M.D., Hand Surgery Associates of New Jersey, for his help in the preparation of this manuscript.

\section{References}

1) F. Miller, R. Abrams, A. Dorfman, and M. Klein: Science, 96, 428-429 (1942).

2) N. M. Islam, T. Motohiro, and T. Itakura: Nippon Suisan Gakkaishi, 51, 811-815 (1985).

3) N. M. Islam, T. Motohiro, and T. Itakura: Nippon Suisan Gakkaishi, 52, 913-918 (1986)

4) E. Tanikawa: in "Marine products in Japan" (ed. by E. Tanikawa), Koseisha-Koseikaku, Tokyo, 1971, pp. 295-339.

5) S. Lassen: in "Fish as food III" (ed. G. Borgstrom), Academic Press, New York, 1965, pp. 281-299.

6) S. Konosu: in "Food taste chemistry" (ed. by J. C. Boudreau), ACS, Washington, D. C., 1979 pp. 185-203.

7) M. Murata and M. Sakaguchi: J. Food Sci., 51, 321-326 (1986). 